\title{
The work of the nursing team in the operating room and the health-related damages
}

\author{
O trabalho da equipe de enfermagem no centro \\ cirúrgico e os danos relacionados à saúde \\ El trabajo del personal de enfermería en el quirófano \\ y los daños relacionados com la salud
}

\section{Bruna Pires Madrid ${ }^{\mathrm{a}}$ Cecília Helena Glanznerb}

\section{How to cite this article:}

Madrid BP, Glanzner $\mathrm{CH}$. The work of the nursing team in the operating room and the health-related damages. Rev Gaúcha Enferm. 2021:42(spe):e20200087. doi: https://doi.org/10.1590/19831447.2021.20200087 a Pesquisadora Autônoma. Porto Alegre, Rio Grande do Sul, Brasil.

Universidade Federal do Rio Grande do Su (UFRGS), Escola de Enfermagem, Departamento de Enfermagem Médico-Cirúrgica. Porto Alegre, Rio Grande do Sul, Brasil.

\section{ABSTRACT}

Objectives: to analyze the work of the nursing team in the operating room and the physical, psychological, and social damage related to occupational health.

Methods: quantitative study conducted from November 2017 to January 2018 in the operating room of a university hospital. The sample consisted of 160 nursing workers who responded to the Work-Related Damage Assessment Scale. Data were analyzed using the Student's t test, One-Way analysis of variance (ANOVA) followed by Pearson's chi-square test.

Results: psychological and social damage were assessed by workers as low risk by $86.8 \%(139)$ and $87.4 \%$ (140), respectively. Physical damage was considered a medium risk by $57.9 \%$ (93) of the sample.

Conclusions: the results direct the attention of managers and the occupational medicine service to physical damage, preventing them from getting worse and thus promoting improvements in working conditions and occupational health.

Keywords: Perioperative nursing. Nursing. Operating room nursing. Occupational health. Occupational health nursing. Nursing, team.

\section{RESUMO}

Objetivos: analisar o trabalho da equipe de enfermagem no centro cirúrgico e os danos físicos, psicológicos e sociais relacionados à saúde do trabalhador.

Métodos: estudo quantitativo realizado de novembro de 2017 a janeiro de 2018 no centro cirúrgico de um hospital universitário. Amostra foi composta por 160 trabalhadores de enfermagem que responderam a Escala de Avaliação de Danos Relacionados ao Trabalho. Os dados foram analisados por meio do teste t de Student, análise de variância One-Way (ANOVA) seguido do teste de qui-quadrado de Pearson.

Resultados: danos psicológicos e sociais foram avaliados pelos trabalhadores como risco baixo por 86,8\% (139) e 87,4\% (140), respectivamente. Danos físicos apresentaram risco médio por 57,9\% (93) da amostra.

Conclusões: os resultados direcionam a atenção dos gestores e serviço de medicina ocupacional para os danos físicos, evitando que se agravem e assim promover melhorias nas condições de trabalho e na saúde do trabalhador.

Palavras-chave: Enfermagem perioperatória. Enfermagem. Enfermagem de centro cirúrgico. Saúde do trabalhador. Enfermagem do trabalho. Equipe de enfermagem.

\section{RESUMEN}

Objetivos: analizar el trabajo del equipo de enfermería en el quirófano y el daño físico, psicológico y social relacionado con la salud del trabajador.

Métodos: estudio cuantitativo realizado de noviembre de 2017 a enero de 2018 en el quirófano de un hospital universitario. La muestra estuvo conformada por 160 trabajadores de enfermería que respondieron a la Escala de Evaluación de Daños Relacionados con el Trabajo. Los datos se analizaron mediante la prueba t de Student, análisis de varianza unidireccional (ANOVA) seguido de la prueba de chi-cuadrado de Pearson.

Resultados: los daños psicológicos y sociales fueron evaluados por los trabajadores como de bajo riesgo en un 86,8\% (139) y un 87,4\% (140), respectivamente. El daño físico presentó un riesgo promedio para el 57,9\% (93) de la muestra.

Conclusiones: los resultados dirigen la atención de los gerentes y del servicio de medicina del trabajo hacia el daño físico, evitando su agravamiento y promoviendo así mejoras en las condiciones de trabajo y salud del trabajador.

Palabras clave: Enfermería perioperatoria. Enfermería. Enfermaría de quirófano. Salud laboral. Enfermería del trabajo. Grupo de enfermería. 


\section{口INTRODUCTION}

In the Operating Room (OR) invasive interventions are performed that demand materials of high precision and efficacy, requiring people who are trained to develop work processes that require specific knowledge of technology and skills to face unique situations in the units that make up the area ${ }^{(1)}$.

In addition, the OR presents itself as a very dynamic, unpredictable, and immedicable work sector, which often prevents it from maintaining a planning of activities in general, resulting in work overload. These factors contribute to the stress, especially for nursing workers, who have the role of providing direct patient care and supporting other members of the surgical team ${ }^{(2)}$.

Even with these issues, work is considered essential for the individual as it constitutes their identity through achievement, skills development, growth and personal satisfaction ${ }^{(3)}$.

On the other hand, the organization of work can limit the professional's participation in daily decisions and unforeseen events, because they take away the worker's dynamism and creativity, and when these experiences accumulate for a prolonged period of time, they contribute to a series of injuries to physical and psychological health of the worker, that is, they can cause psychological, physical and/or social damage ${ }^{(4)}$. Psychological damage is characterized by negative feelings about oneself and life in general, as social damage is defined as isolation behaviors and difficulties in family/ social relationships and physical damage is related to body pain and biological disorders ${ }^{(4)}$.

In a report by the International Labour Organization ${ }^{(5)}$ it is estimated that 2.34 million people die each year in the world as a result of accidents and work-related illnesses, highlighting as emerging risks poor ergonomic conditions, exposure electromagnetic radiation and psychosocial risks, and few studies address the issue of psychosocial risks related to work in the operating room.

In view of this, it is important to analyze the damages that affect nursing workers in the operating room in order to promote better working conditions, since the number of nursing professionals is progressively decreasing throughout the world. Because of this, the Nursing Now campaign was created in collaboration with the World Health Organization and the International Council of Nurses with the objective of raising the status and profile of nursing through the recognition of the profession to avoid further reduction in the workforce of these professionals and not impairing health care on a global scale $e^{(6)}$.

Given the above, the following question arises: does work in the operating room cause physical, psychological, and social damage to the nursing worker? The nursing team is daily exposed to occupational risks, highlighting the chemical, biological, ergonomic, physical, and psychosocial risks that can cause damage to the health of these workers and generate consequences such as illness, leaves from work activities and affect the quality of care to patient, family and community. Therefore, the objective of this study was to analyze the work of the nursing team in the operating room and the physical, psychological, and social damage related to workers' health. It is believed that the study can be set as a tool to assist health institutions to improve the working conditions of the nursing team in $\mathrm{OR}$.

\section{METHOD}

Descriptive, analytical study with a quantitative approach conducted from November 2017 to January 2018 with nursing workers in the operating room of a university hospital located in the capital of the State of Rio Grande do Sul - Brazil.

The operating room comprises the Operating Room Unit $(\mathrm{ORU})$, the Ambulatory Surgery Center (ASC), the Post-Anesthesia Care Unit (PACU) and the Central Sterile Supplies Department (CSSD) ${ }^{(7)}$.

The ORU serves patients of low, medium, and high complexity in the intraoperative period of conventional, videolaparoscopic and robotic surgeries, attending an average of 40 daily surgeries of medium and large size. The PACU assists adult and pediatric patients in the immediate recovery of surgical procedures from the ORU. The ASC, on the other hand, attends to surgical patients of low and medium complexity outpatients in conventional surgeries, laparoscopic surgeries, endoscopic exams, and patients recover in the first hours in the Immediate Recovery and Sedation Room. The CSSD attends to all the processes of disinfection and sterilization of the hospital's reprocessed products ${ }^{(7)}$.

The population of the operating room consisted of 350 professionals and 160 nursing workers comprised the sample, for this, a statistical calculation was performed, possible to detect a difference in effect size greater than or equal to 0.25 of the surgical units, considering a power of $80 \%$ and a significance level of 0.05 . These professionals were randomly selected until reaching the required number of the sample. Data collection was performed individually with the professionals and the research instrument was delivered during the workday, filled out by them outside the work day and collected after the agreed date.

The workers who composed the sample were nurses, technicians and nursing assistants working for six months or more in the surgical units, of any work shift, age or gender. 
Those who, at the time of the research, were away, on vacation or on leave for any reason were excluded from the study.

Data collection was performed by a research team composed by four previously trained undergraduate nursing students, totaling 20 hours of guidance on the topic, collection and characteristics of the area conducted by the research coordinator. The instrument applied was the Work-Related Damage Assessment Scale (EADRT), which was identified by an Arabic number. The EADRT scale was created in 2003 with application to 1,916 auditors in partnership with the National Federation of Fiscal Auditors of the Brazilian Social Security (Fenafisp) and later revalidated in 2004 with 5,437 workers from federal public companies in the Federal District. Its psychometric validation was based on the factor analysis technique. This is one of the four scales that make up the Psychosocial Risk Assessment Protocol at Work (PROART) $)^{(4)}$ and its items refer to the physical, psychological and social damages caused by the confrontation with a given work organization and, at the end of the scale data related to function, gender of the worker, work shift, age, work time in the unit and in the institution, work activity, smoking habit, quality and hours of sleep are gathered ${ }^{(4)}$.

The EADRT is composed by 23 items and divided into three factors: psychological damage (items 1 to 7), social damage (items 8 to 14) and physical damage (items 15 to 23). It is assessed from a Likert frequency scale consisting of five points: 1 - Never; 2 - Rarely; 3 - Sometimes; 4 - Frequently; 5 - Always ${ }^{(4)}$.

According to the parameters established by the scale, it was considered the standard deviation in relation to the midpoint and, for the assessment of the mean and frequency of the factors, the following were considered: values between 1.00 to 2.29 have low risk and are characterized as a positive result; values between 2.30 to 3.69 present medium risk, considered a median result and represent a state of alert/limit situation for damages and demand for interventions in the short and medium term; values between 3.70 and 5.00 have a high risk, being a negative result because they represent high damage and demand for immediate interventions in the causes aiming to eliminate and/or mitigate them ${ }^{(4)}$.

In addition, the EADRT global analysis takes into account the following criteria: the overall risk will be considered low when the three factors are assessed or when two factors are assessed as low risk and one as medium; it will be considered medium when three factors are assessed as medium risk, two factors as medium and one as low, or when one factor is assessed as high risk and the others as low; the overall risk will be considered high when two factors present high risks or one presents as high and the others medium ${ }^{(4)}$.
The data were organized and double-entered into an Excel spreadsheet by the four nursing students, and then analyzed using the software Statistical Package for Social Sciences (SPSS) version 22.0. Descriptive analysis was performed using simple and relative frequencies for categorical variables, of central tendency (mean or median) and dispersion measures (standard deviation and quartiles) for continuous variables. To compare EADRT factors between sociodemographic and occupational variables, Student's $t$ test and One-Way Analysis of Variance (ANOVA) were used, followed by Pearson's chi-square test and multiple comparisons test of the least significant differences when necessary. The characteristics that had $P$ values $<0.20$ were included in multiple linear regression analyzes (one for each type of damage) to identify the variables that influenced work-related damages. For this analysis, $\mathrm{P}$ values $<0.05$ were considered significant.

This study was approved by the Research Ethics Committee of the institution - CAAE: 65993517.9.0000.5327 and complied with the ethical criteria established by Resolution no. $466 / 2012^{(8)}$. The selected nursing workers were invited to participate in the research voluntarily and those who agreed to participate in the study signed the Free and Informed Consent Form (FICF), which states the researcher's commitment to preserve the collected data and the identity of the participants, being the term signed by the researcher and a copy given to the respondent.

\section{$\square$ RESULTS}

Among the 160 participating nursing workers, the sample consisted of $80.9 \%$ (131) of women with a mean age of 46.7 years ( \pm 8.9 ). Regarding the job function, $62.3 \%$ (101) were nursing technicians, 19.8\% (32) nurses, $11.1 \%$ (19) nursing assistants, and 5\% (8) did not inform their professional category, with $43.2 \%$ (70) reported having only completed high school. The average time of service at the institution was 14 years and 11 months $( \pm 10.4)$.

Regarding the work shift, $34.3 \%$ (55) of the professionals worked at night, 30\% (48) in the afternoon, 28.1\% (45) in the morning and $5 \%$ (8) worked in the intermediate shift or only at the end of week. As for health problems, 43.8\% (71) reported one or two health problems, 92\% (149) had their last medical examination and 59\% (95) had no work leaves, all in relation to the 12 months prior to the study. Regarding life habits, 58\% (94) reported doing some physical activity, 90.1\% (146) denied smoking, 67.3\% (109) reported having a good night's sleep and $63.1 \%$ (101) reported sleeping from 6 to 8 hours. 
Regarding the number of workers who participated in the study per surgical unit, 30\% (48) were from the ORU and $30 \%$ (48) from the ASC, followed by $22.5 \%$ (36) from the CSSD and $17.5 \%$ (28) of the PACU.
Table 1 below shows the mean and standard deviation of the EDART items with their respective risks answered by the study participants.

Table 1 - Mean and standard deviation of the items on the Work-Related Damage Assessment Scale answered by workers in the operating room units of a university hospital. Porto Alegre/RS-Brazil, 2017-2018 (N=160)

\begin{tabular}{|c|c|c|c|c|}
\hline Factor & Items & Mean & SD & Risk \\
\hline \multirow{7}{*}{ Psychological Damage } & Bitterness & 1.53 & 0.8 & Low \\
\hline & Feeling of emptiness & 1.53 & 0.8 & Low \\
\hline & Bad mood & 1.99 & 0.9 & Low \\
\hline & Willingness to give up everything & 1.48 & 0.8 & Low \\
\hline & Sadness & 1.87 & 1.0 & Low \\
\hline & Loss of self-confidence & 1.55 & 0.8 & Low \\
\hline & Loneliness & 1.43 & 0.8 & Low \\
\hline \multirow{7}{*}{ Social Damage } & Insensitivity towards colleagues & 1.76 & 0.9 & Low \\
\hline & Difficulties in relationships outside work & 1.55 & 0.7 & Low \\
\hline & Willingness to be alone & 1.84 & 0.9 & Low \\
\hline & Conflicts in family relationships & 1.74 & 0.8 & Low \\
\hline & Aggressiveness towards others & 1.52 & 0.7 & Low \\
\hline & Difficulty with friends & 1.43 & 0.6 & Low \\
\hline & Impatience with people in general & 1.82 & 0.8 & Low \\
\hline \multirow{9}{*}{ Physical Damage } & Body pain & 2.96 & 1.0 & Medium \\
\hline & Arm pain & 2.78 & 1.2 & Medium \\
\hline & Headache & 2.50 & 1.0 & Medium \\
\hline & Digestive Disorders & 2.19 & 1.1 & Low \\
\hline & Back pain & 3.12 & 1.0 & Medium \\
\hline & Sleep Disorders & 2.64 & 1.3 & Medium \\
\hline & Leg pain & 3.04 & 1.2 & Medium \\
\hline & Circulatory Disorders & 2.12 & 1.2 & Low \\
\hline & Appetite Disorders & 2.07 & 1.2 & Low \\
\hline
\end{tabular}

Source: research data, 2017-2018. 
Based on the results in the table, it is possible to observe that all items of psychological and social damage factors were assessed by the nursing workers in the operating room as low risk. As for work-related physical damage, participants considered six items as a medium risk: body pain, arm pain, headache, sleep disorders, back pain, and leg pain, with the last two items with the highest scores.

These results are homogeneous in relation to the percentage of risk assessment for psychological, social and physical damage, with the highest percentage remaining in low risk for psychological and social, and medium in physical damage, as shown in table 2.

Considering the differences in each area that compose the operating room and their specificities, it is observed that in the operating room, no worker considered that work in the area offered severe risk for psychological or social damage, but $6.4 \%$ considered it a high risk for the physical damage. In the ambulatory surgery center, none of the workers considered high risk for social damage and, for psychological and physical damage, they were considered high by $2.1 \%$ and $8.3 \%$ participants, respectively. In the central sterile supplies department, all damages had some assessment of high psychosocial risk, 2.8\% for psychological and social damage, while physical damage was considered severe by $13.9 \%$ of the team. At the PACU, none of the workers considered that their work activities offered high social risk, while 3.6\% considered it high risk for psychological and physical damage.

The next table presents the variables of the sociodemographic and occupational groups compared to work-related damages that presented $P$ values $<0.20$. This table does not include the variables gender, education, physical activity, and hours of sleep, as they did not present statistically significant values.

The variables presented in table 3 were included in three different multiple linear regression models $(n=143)$ for each type of damage. For psychological damage, time

Table 2 - Percentage of risk assessment for psychological, social and physical damage by workers in the operating room units of a university hospital. Porto Alegre/RS-Brazil, 2017-2018 ( $N=160)$

\begin{tabular}{|c|c|c|c|c|c|c|}
\hline Factor & ORU & ASC & CSSD & PACU & All & P* \\
\hline Psychological Damage & & & & & & 0.718 \\
\hline Low risk & $91.5 \%$ & $89.6 \%$ & $80.6 \%$ & $82.1 \%$ & $86.8 \%$ & \\
\hline Medium risk & $8.5 \%$ & $8.3 \%$ & $16.7 \%$ & $14.3 \%$ & $11.3 \%$ & \\
\hline High risk & $0 \%$ & $2.1 \%$ & $2.8 \%$ & $3.6 \%$ & $1.9 \%$ & \\
\hline Social Damage & & & & & & 0.299 \\
\hline Low risk & $89.4 \%$ & $93.8 \%$ & $77.8 \%$ & $85.7 \%$ & $87.4 \%$ & \\
\hline Medium risk & $10.6 \%$ & $6.3 \%$ & $19.4 \%$ & $14.3 \%$ & $11.9 \%$ & \\
\hline High risk & $0 \%$ & $0 \%$ & $2.8 \%$ & $0 \%$ & $0.6 \%$ & \\
\hline Physical Damage & & & & & & 0.224 \\
\hline Low risk & $29.8 \%$ & $43.8 \%$ & $36.1 \%$ & $21.4 \%$ & $34 \%$ & \\
\hline Medium risk & $63.8 \%$ & $47.9 \%$ & $50 \%$ & $75 \%$ & $57.9 \%$ & \\
\hline High risk & $6.4 \%$ & $8.3 \%$ & $13.9 \%$ & $3.6 \%$ & $8.2 \%$ & \\
\hline
\end{tabular}

Source: research data, 2017-2018.

Notes: *P values obtained from Pearson's chi-square test analysis. 
Table 3 - Comparisons of scale factors between the categories of sociodemographic and occupational variables of workers in the operating room units of a university hospital. Porto Alegre/RS-Brazil, 2017-2018 (N=160)

\begin{tabular}{|c|c|c|c|c|}
\hline Variable & & $\begin{array}{c}\text { Psychological } \\
\text { Damage }\end{array}$ & Social Damage & Physical Damage \\
\hline \multirow{5}{*}{ Work shift } & Morning & $1.56 \pm 0.47^{\ddagger}$ & $1.58 \pm 0.47^{\ddagger}$ & $2.58 \pm 0.63^{\ddagger}$ \\
\hline & Afternoon & $1.68 \pm 0.77^{\ddagger}$ & $1.76 \pm 0.63^{\ddagger}$ & $2.77 \pm 0.97^{\ddagger}$ \\
\hline & Night & $1.67 \pm 0.66^{\ddagger}$ & $1.70 \pm 0.56^{\ddagger}$ & $2.59 \pm 0.80^{\ddagger}$ \\
\hline & Others & $1.39 \pm 0.41^{\ddagger}$ & $1.45 \pm 0.36^{\ddagger}$ & $2.02 \pm 0.82^{\ddagger}$ \\
\hline & $P^{*}$ & 0.467 & 0.241 & 0.058 \\
\hline \multirow{3}{*}{ Age } & $<45$ years & $1.54 \pm 0.68^{\ddagger}$ & $1.55 \pm 0.51^{\ddagger}$ & $2.53 \pm 0.82^{\ddagger}$ \\
\hline & $=>45$ & $1.64 \pm 0.58^{\ddagger}$ & $1.76 \pm 0.56^{\ddagger}$ & $2.63 \pm 0.84^{\ddagger}$ \\
\hline & $P^{* *}$ & 0.346 & 0.027 & 0.464 \\
\hline \multirow{4}{*}{ Function } & Nurse & $1.61 \pm 0.69^{\ddagger}$ & $1.65 \pm 0.56^{\ddagger}$ & $2.38 \pm 0.90^{\ddagger}$ \\
\hline & Nurse technician & $1.60 \pm 0.60^{\ddagger}$ & $1.63 \pm 0.53^{\ddagger}$ & $2.61 \pm 0.77^{\ddagger}$ \\
\hline & Others & $1.50 \pm 0.50^{\ddagger}$ & $1.72 \pm 0.61^{\ddagger}$ & $2.84 \pm 0.94^{\ddagger}$ \\
\hline & $P^{*}$ & 0.815 & 0.805 & 0.140 \\
\hline \multirow{5}{*}{$\begin{array}{c}\text { Time of service at } \\
\text { the institution }\end{array}$} & Up to 5 years & $1.45 \pm 0.63^{\ddagger a}$ & $1.54 \pm 0.63^{\ddagger}$ & $2.34 \pm 0.99^{\neq}$ \\
\hline & 5 to 10 years & $1.60 \pm 0.59^{\ddagger a b}$ & $1.63 \pm 0.53^{\ddagger}$ & $2.67 \pm 0.65^{\ddagger}$ \\
\hline & 10 to 20 years & $1.79 \pm 0.70^{\ddagger b}$ & $1.73 \pm 0.49^{\ddagger}$ & $2.78 \pm 0.90^{\ddagger}$ \\
\hline & $>20$ years & $1.48 \pm 0.46^{\ddagger a}$ & $1.63 \pm 0.52^{\ddagger}$ & $2.48 \pm 0.65^{\ddagger}$ \\
\hline & $P^{*}$ & 0.042 & 0.481 & 0.092 \\
\hline \multirow{4}{*}{ Health problems } & No problem & $1.44 \pm 0.51^{\ddagger a}$ & $1.55 \pm 0.51^{\ddagger a}$ & $2.18 \pm 0.68^{\ddagger a}$ \\
\hline & 1 or 2 problems & $1.63 \pm 0.54^{\ddagger a}$ & $1.66 \pm 0.54^{\ddagger a b}$ & $2.73 \pm 0.67^{ \pm b}$ \\
\hline & 3 or more problems & $1.97 \pm 0.89^{\neq b}$ & $1.93 \pm 0.51^{\neq b}$ & $3.38 \pm 1.00^{\ddagger c}$ \\
\hline & $P^{*}$ & 0.004 & 0.032 & 0.000 \\
\hline \multirow{3}{*}{ Last medical test } & Yes & $1.52 \pm 0.54^{\ddagger}$ & $1.60 \pm 0.52^{\ddagger}$ & $2.41 \pm 0.81^{\ddagger}$ \\
\hline & No & $1.70 \pm 0.64^{\ddagger}$ & $1.69 \pm 0.55^{\ddagger}$ & $2.83 \pm 0.72^{\ddagger}$ \\
\hline & $P^{* *}$ & 0.217 & 0.037 & 0.224 \\
\hline
\end{tabular}


Table 3 - Cont.

\begin{tabular}{|c|c|c|c|c|}
\hline Variable & & $\begin{array}{c}\text { Psychological } \\
\text { Damage }\end{array}$ & Social Damage & Physical Damage \\
\hline \multirow{3}{*}{ Work leave } & No & $1.52 \pm 0.54^{\ddagger}$ & $1.60 \pm 0.52^{\ddagger}$ & $2.42 \pm 0.81^{\ddagger}$ \\
\hline & Yes & $1.74 \pm 0.71^{\ddagger}$ & $1.72 \pm 0.56^{\ddagger}$ & $2.87 \pm 0.80^{\ddagger}$ \\
\hline & $P^{* *}$ & 0.028 & 0.206 & 0.001 \\
\hline \multirow{3}{*}{ Smoking } & Não & $1.62 \pm 0.63^{\ddagger}$ & $1.66 \pm 0.54^{\ddagger}$ & $2.59 \pm 0.84^{\ddagger}$ \\
\hline & $\operatorname{Sim}$ & $1.35 \pm 0.32^{\ddagger}$ & $1.46 \pm 0.49^{\ddagger}$ & $2.74 \pm 0.86^{\ddagger}$ \\
\hline & $P^{* *}$ & 0.196 & 0.277 & 0.594 \\
\hline \multirow{3}{*}{ Sleep quality } & Ruim & $1.78 \pm 0.75^{\ddagger}$ & $1.83 \pm 0.59^{\ddagger}$ & $3.05 \pm 1.04^{\ddagger}$ \\
\hline & Boa & $1.54 \pm 0.54^{\ddagger}$ & $1.57 \pm 0.50^{\ddagger}$ & $2.41 \pm 0.65^{\ddagger}$ \\
\hline & $P^{* *}$ & 0.030 & 0.006 & 0.000 \\
\hline
\end{tabular}

Source: research data, 2017-2018.

Notes: $:$ Values are presented as mean and standard deviation (mean \pm SD).

*P value obtained from the analysis of variances. For the means followed by the same letters, there was no statistically significant difference ( $a=0.05$ ) by the test of multiple comparisons of the least significant differences.

**P value obtained from Student's t test

of service, health problems, work leave, smoking and sleep quality were included, with only health problems remaining significant $(p=0.019)$.

In the social damage age, health problems, last medical examination and sleep quality were included, maintaining significant only sleep quality ( $p=0.019)$. The physical damage included work shift, function, time of service at the institution, health problems, work leave and sleep quality. The variables that remained significant were health problems $(p=0.001)$, sleep quality $(p=0.000)$, time of service at the institution $(p=0.082)$ and work leave $(p=0.047)$.

\section{DISCUSSION}

Based on the sociodemographic information, there is a predominance of females (80.9\%) in the sample, reinforcing the sociocultural heritage that aims at the nursing category as a female profession focused on caring for others and associated with the maternal instinct today ${ }^{(9)}$. The average age of nursing workers was 46.7 years $( \pm 8.9)$. As for the time of service at the institution, the sample had an average of 14 years and 11 months ( \pm 10.4 ), which highlights the broad experience and professional trajectory of the sample.
Regarding the results of the EADRT, both psychological damage and social damage were at low risk for the nursing workers studied, however, the items with the highest scores between the two factors were bad mood, sadness, willingness to be alone and impatience. The OR has some organizational characteristics such as demand for productivity and agility for greater rotation of procedures, which can lead to professional devaluation, providing negative feelings, such as anxiety, irritability, nervousness and tension ${ }^{(10)}$.

On the other hand, physical damage was the factor that had more than half of its items assessed as Medium risk of developing work-related damage, with back pain and leg pain being highlighted. In a study conducted in the southern region of Brazil with 95 nurses from 4 different hospitals who worked in surgical clinic, physical damage was also identified as the factor with the highest mean and the same 2 items in evidence, however the general classification of this factor was as a critical level ${ }^{(11)}$.

In addition, a study conducted with a nursing team working in OR showed that most workers had some musculoskeletal symptom in the 12 months prior to the research, this is due to the fact that nurses perform their activities most of the time standing or walking ${ }^{(12)}$. 
The PACU was the unit that presented the highest risk for work-related physical damage in this study. Patients in post-anesthetic recovery demand constant nursing care as they are more vulnerable to complications during this period and, when they occur, they need immediate assistance to reestablish the physiological balance ${ }^{(7-13)}$. Therefore, this demand for constant care and prolonged patient displacement leaves professionals physically vulnerable.

Based on the findings of this study, two factors, psychological damage and social damage, presented low risks and only the physical damage factor presented medium risk, so the global assessment of the scale, according to the instrument used $^{(4)}$, is considered as a low risk of work-related damage. These results are in line with a study conducted with a multidisciplinary health team from the Mobile Emergency Care Service (SAMU) of the Federal District ${ }^{(14)}$ that used PROART, where most professionals presented low and medium risk of psychological, social and physical damage, as well as in another study, which showed similar results in a hemodialysis service in southern Brazil ${ }^{(15)}$.

Work-related stress and the consequences it can bring to health have become a worrying issue in recent times, prolonged stress can lead to the development of musculoskeletal, heart and digestive system diseases, as well as promote increased anxiety and depression and other mental disorders ${ }^{(5)}$. These data are in line with what was found in this study, where Psychological and Physical Damage were associated with worsening health. Professional burnout among health professionals is on the rise and reinforces the importance of providing tools to deal with stressors and the emotional challenges they face on a daily basis ${ }^{(16)}$.

In the present study, poor sleep quality was related to physical and social damage. When this is insufficient, there is a reduction in the performance of their productivity, a decrease in their ability to concentrate and pay attention, putting their physical integrity and also the safety of others at risk. Furthermore, it influences the body's metabolism, being related to obesity and chronic diseases such as diabetes ${ }^{(17)}$.

Workers who had greater physical damage were associated with time of service at the institution, as well as in the study conducted in the emergency room of a hospital in the countryside of São Paulo(18). In this study, nursing professionals with injuries or illnesses had a higher mean the longer they worked in the unit and in the hospital institution ${ }^{(18)}$.

Physical damage was also related to work leave in the studied professionals. Similarly to another study, which aimed to identify the occurrences of health problems for nursing workers in a public educational institution, observing that of the 1,847 occurrences, $86.63 \%$ were related to medical leaves related to causes such as musculoskeletal injuries and $7.96 \%$ to work accidents with leave ${ }^{(19)}$.

However, the work requires from professionals a practice of organizing activities, implied in relationships that provide pleasure and/or suffering. Emphasizing the importance of health studies on this theme, since to be continent with the suffering of the other, the health worker must, in their work, be able to negotiate their desires with organizational demands to avoid suffering.

\section{CONCLUSIONS}

The results of the study allow us to conclude that the specificity of the work of the nursing team in the operating room can lead to physical, psychological, and social damage to workers. The workers surveyed considered that work offers a low risk for psychological and social damage. However, the items back pain and leg pain that are included in the physical damage factor presented a medium risk, being an alert that needs attention from managers and occupational medicine service in the short and medium term to ensure the occupational health and promote improvements in work conditions.

The results presented are positive and extremely important for the institution and patients, as these are different work contexts that require special nursing attention to minimize and prevent complications in the health of patients during the surgery period, which requires highly complex care.

A limitation of the study is that its results reflect the context of an institution, which makes it impossible to generalize these data. Therefore, it is suggested that further studies on psychosocial risks in this area to be encouraged, along with other emerging risks, such as poor ergonomic conditions and exposure to electromagnetic radiation.

It is concluded that the work context of health institutions, specifically the operating room, due to its specificities and because it is constantly changing, must be assessed to promote working conditions that enable the maintenance of workers' health through their potential and abilities, to ensure their quality of life and the quality of care provided to patients, family, and community.

\section{REFERENCES}

1. Martins FZ, Dall'Agnol CM. Surgical center: challenges and strategies for nurses in managerial activities. Rev Gaúcha Enferm. 2016;37(4):e56945. doi: https:// doi.org/10.1590/1983-1447.2016.04.56945.

2. Jacques JPB, Ribeiro RP, Martins JT, Rizzi DS, Schmidt DRC. Geradores de estresse para os trabalhadores de enfermagem de centro cirúrgico. Semina Cienc Biol Saude. 2015;36(1):25-32. doi: http://doi.org/10.5433/1679-0367.2015v36n1Suplp25. 
3. Duarte JMG, Simões ALA. Significados do trabalho para profissionais de enfermagem de um hospital de ensino. Rev Enferm UERJ. 2015;23(3):388-94. doi: http://doi.org/10.12957/reuerj.2015.6756.

4. Facas EP, Mendes AM. Estrutura fatorial do protocolo de avaliação dos riscos psicossociais no trabalho [internet]. Núcleo Trabalho, Psicanálise e Crítica Social; 2018 [cited 2019 Apr 19]. Available from: http://nucleotrabalho.com.br/wpcontent/uploads/2018/12/Facas-Mendes-Estrutura-Fatorial-do-Protocolo-deAvalia\%C3\%A7\%(3\%A30-dos-Riscos-Psicossociais-no-Trabalho1.pdf.

5. Organização das Nações Unidas. Organização Internacional do Trabalho. Constituição da Organização Internacional do Trabalho (0IT) e seu anexo (Declaração de Filadélfia). 2019 [cited 2019 0ct 06]. Available from: https://www.lo.org/ wcmsp5/groups/public/---americas/---ro-lima/---ilo-brasilia/documents/ genericdocument/wcms_336957.pdf.

6. Benton DC, Beasley CJ, Ferguson SL. Nursing now! learning from the past, positioning for the future. Online J Issues Nurs. 2019;24(2):Manuscript 5 [cited 2020 Jan 20]. Available from: https://ojin.nursingworld.org/MainMenuCategories/ ANAMarketplace/ANAPeriodicals/OJIN/TableofContents/Vol-24-2019/No2May-2019/Nursing-Now-Learning-from-Past.html

7. Associação Brasileira de Enfermeiros de Centro Cirúrgico, Recuperação Anestésica e Centro de Material e Esterilização (SOBECC). Diretrizes de práticas em enfermagem cirúrgica e processamento de produtos para a saúde. 7. ed. Barueri: Manole; 2017.

8. Ministério da Saúde (BR). Conselho Nacional de Saúde. Resolução no 466, de 12 de dezembro de 2012. Aprova diretrizes e normas regulamentadoras de pesquisas envolvendo seres humanos. 2012 dez 12 [cited 2020 Jan 18]. Available from: https://bvsms.saude.gov.br/bvs/saudelegis/cns/2013/res0466_12_12_2012. html.

9. Santos, C. Características da violência perpetrada por pacientes e familiares a trabalhadores de enfermagem em hospital universitário [trabalho de conclusão]. Porto Alegre: Universidade Federal do Rio grande do Sul; 2015 [cited 2018 Jun 18]. Available from: http://www.lume.ufrgs.br/bitstream/ handle/10183/135493/000987011.pdf?sequence=1.
10. Tostes MFP, Silva AQ, Garçon TL, Maran E, Teston EF. Duality between fulfilment and suffering in the work of the nursing staff in operating rooms. Rev SOBECC. 2017;22(1):3-9. doi: http://doi.org/10.5327/Z1414-4425201700010002.

11. Silva RM, Zeitoune RCG, Beck CLC, Martino MMF, Prestes FC. The effects of work on the health of nurses who work in clinical surgery departments at university hospitals. Rev Latino-Am Enfermagem. 2016;24:e2743. doi http:// doi.org/10.1590/1518-8345.0763.2743.

12. Schmidt DRC, Dantas RAS. Quality of work life and work-related musculoskeletal disorders among nursing professionals. Acta Paul Enferm. 2012;25(5):701-7. doi: https://doi.org/10.1590/S0103-21002012000500009.

13. Lima $L B$, Rabelo ER. Nursing workload in the post-anesthesia care unit. Acta Paul Enferm. 2013;26(2):116-22. doi: https://doi.org/10.1590/ S0103-21002013000200003.

14. Araujo LKR. Protocolo de avaliação dos riscos psicossociais: adequação ao SAMUDF [dissertação]. Rio de Janeiro: Escola Nacional de Saúde Pública Sérgio Arouca, Fundação Oswaldo Cruz; 2017. [cited 2018 Jun 02]. Available from: https://www. arca.fiocruz.br/handle/icict/24062.

15. Prestes FC, Beck CLC, Magnago TSBS, Silva RM, Coelho APF. Health problems among nursing workers in a haemodialysis service. Rev Gaúcha Enferm. 2016.37(1):e50759. doi: http://doi.org/10.1590/1983-1447.2016.01.50759.

16. Cole SP. Burnout Prevention and Resilience. Int Anesthesiol Clin. 2019;57(2):11831. doi: https://doi.org/10.1097/AIA.0000000000000230.

17. Caruso CC. Negative impacts of shiftwork and long work hours. Rehabil Nurs. 2014;39(1):16-25. doi: https://doi.org/10.1002/rnj.107.

18. Bordignon M, Monteiro MI. Problemas de salud entre profesionales de enfermería y factores relacionados. Enferm Glob. 2018;17(3):435-69. doi: https://doi. org/10.6018/eglobal.17.3.302351.

19. Bernardes CL, Vasconcelos LHS, Silva SM, Baptista PCP, Felli VEA, Pustiglione M, et al. Health problems of nursing workers in a public educational institution. Rev Esc Enferm USP. 2014;48(4):677-83. doi: https://doi.org/10.1590/ S0080-623420140000400015. 
Madrid BP, Glanzner CH

\section{- Authorship contribution:}

Conceptualization - Bruna Pires Madrid e Cecília

Helena Glanzner.

Data curation - Bruna Pires Madrid e Cecília Helena

Glanzner.

Formal analysis - Bruna Pires Madrid e Cecília Helena

Glanzner.

Investigation - Bruna Pires Madrid.

Methodology - Bruna Pires Madrid e Cecília Helena

Glanzner.

Project administration - Cecília Helena Glanzner.

Resources - Cecília Helena Glanzner.

Software - Bruna Pires Madrid e Cecília Helena

Glanzner.

Supervision - Cecília Helena Glanzner.

Validation - Bruna Pires Madrid e Cecília Helena

Glanzner.

Visualization - Bruna Pires Madrid e Cecília Helena

Glanzner.

Writing-original draft - Bruna Pires Madrid.

Writing-review \& editing - Bruna Pires Madrid e Cecília

Helena Glanzner.

The authors declare that there is no conflict of interest.

\section{- Corresponding author:}

Cecília Helena Glanzner

E-mail: glanznercecilia@gmail.com

\section{Associate editor:}

Dagmar Elaine Kaiser

Editor-in-chief:

Approved: 07.09.2021
Maria da Graça Oliveira Crossetti 